\title{
Nilai dan Pendidikan Nilai di Sekolah
}

\author{
H. Agus Maimun \\ Penulis adalah dosen tetap Fakultas Tarbiyah UIN Malang \\ dan kandidat doctor Universitas Negeri Jakarta (UNJ)
}

\section{Abstract}

Value is the essence which causes it to be appropriate to be done by human beings. Value has close relationship with goodness. Although both of them are not same, remembering that a good thing does not always have high value for someone or on the contrary; in order value to be a part of individual, then it needs to be given through educational process. Educational value is not only one thing that increases. On the other hand, it is an essential thing in the whole educational process. Some religious values and humanity values that need to be tought in educational process in school are ikhlas, tawaddu', ashamed, qonaah, zuhud, iffah, eagerness, honest, care ness and emparhy, cooperative, brave, great heart and commitment, fear, like helping, honesty and integrity, humor, independence and self confidence, self discipline, loyalty, patient, feel proud, cleaver, respect, responsible and tolerance. However, approach that is used in educational value includes evocation approach, inculcation approach, awareness approach, moral reasoning, value analyses approach, value clarification, commitment approach, and union approach. 


\section{Pengantar}

Sasaran pembangunan pendidikan di Indonesia adalah untuk mewujudkan manusia yang beriman dan bertaqwa kepada Tuhan Yang Maha Esa, berbudi pekerti yang luhur, tangguh, sehat, cerdas, patriotik, berdisiplin, kreatif, produktif, dan profesional demi tetap mantapnya budaya bangsa yang beradab, bermartabat, sesuai jati diri dan kepribadian bangsa. Di samping itu, agar tercipta suasana kehidupan yang harmonis dan berlandaskan pada nilai-nilai universal yang bersumber dari ajaran agama, maka dikembangkan pula nilai-nilai ketuhanan (values of God) dan nilai-nilai kemanusiaan (values of human being) dalam proses pendidikan di sekolah' .

Pada negara berkembang seperti Indonesia yang beragam atau majemuk dalam pengertian etnis, rasial, dan keagamaan, relatif sulit untuk menemukan dan mengembangkan nilai-nilai universal yang merupakan nilai bersama (common). Namun demikian, nilai pendidikan universal merupakan proses belajar terusmenerus bagi semua orang dan semua golongan. Untuk itu, perlu terus dikaji. dikembangkan, dan diupayakan dalam proses pendidikan, agar dapat menemukan materi. model, dan strategi pendidikan nilai yang relevan dengan perkembangan peserta didik dan tuntutan jaman ?

Upaya menemukan materi, model, dan strategi pendidikan nilai ini merupakan suatu keniscayaan. Karena sekarang ini generasi muda kita telah banyak yang terjangkit penyakit "dekadensi moral". Hal ini dapat kita lihat pada tahun-tahun terakhir ini di bumi Indonesia tercinta ada fenomena kekerasan, seperti perampasan hak. perkosaan, perampasan kebebasan, pencurian, penggunaan obat terlarang, minum-muniman keras, perkelahian. dsb yang terjadi terus-menerus dan di manamana dalam skala yang makin luas dan serius.

Semua itu seolah menjadi tontonan seluruh penduduk bumi dan memberikan gambaran yang buruk mengenai citra Indonesia sebagai suatu negara bangsa yang sedang berusaha untuk menuju masyarakat madani. Mengapa itu semua bisa terjadi pada bangsa kita, yang sebelumnya dikenal sebagai bangsa yang religius, ramah, suka bergotong royong, suka bertoleransi, suka hidup dalam damai dan kerukunan, dan berbudaya tinggi? Untuk sementara, mungkin jawabannya adalah merupakan akibat dari kegagalan sektor pendidikan dalam melaksanakan pendidikan nilai-nilai universal. Nilai-nilai luhur dan universal yang ditanamkan 
dan disosialisasikan di sekolah, tampaknya tidak mempribadi pada diri peserta didik. Padahal orang tua dan masyarakat telah mempercayakan pendidikan anakanak mereka sepenuhnya pada sekolah ${ }^{3}$. Karena mereka menganggap bahwa sekolah mampu menjadikan anak-anak mereka ber-budi pekerti luhur (al-akhlaq al-karimah).

Melihat realitas tersebut, kita menyaksikan betapa tingginya intensitas pelanggaran nilai di republik ini. Ditambah lagi dengan adanya berbagai tindakan yang tidak etis yang dipertontonkan oleh para oknum pejabat dan tokoh masyarakat yang hampir merajalela di berbagai sektor kehidupan, seperti korupsi, kolusi, dan nepotisme (KKN) yang mengakibatkan runtuhnya martabat bangsa. Hal ini menunjukkan indikasi bahwa pendidikan nilai yang berlangsung selama ini belum memberikan hasil yang optimal dan sesuai sasaran. Ternyata ilmu dan teknologi tjdak mampu memberikan makna peningkatan kecerdasan yang sebenarnya, kalau tidak disertai dengan nilai yang kokoh. Untuk itu, disinilah pentingnya pendidikan nilai diberikan sejak dini di keluarga dan sekolah, agar mereka mempunyai kesadaran nilai yang tinggi yang pada gilirannya dapat memotivasi mereka untuk berperilaku yang baik sesuai nilai-nilai kemanusiaan dan ketuhanan ${ }^{4}$.

Di samping itu, perlu disadari bahwa pendidikan nilai bukan sesuatu yang hanya ditambahkan, melainkan justeru merupakan sesuatu yang hakiki dalam seluruh proses pendidikan, meskipun sampai sekarang tidak ada mata pelajaran yang khusus mengenai pendidikan nilai. Pendidikan nilai di sekolah selama ini hanya "dititipkan" atau implicit pada mata pelajaran Pendidikan Agama dan Pendidikan Pancasila dan Kewarganegaraan (PPKn) ${ }^{5}$, sehingga hasilnya tidak optimal. Padahal pendidikan nilai bisa dititipkan pada semua mata pelajaran yang ada di sekolah.

Kegagalan tersebut kalau dicermati secara seksama, karena pendidikan nilai yang "dititipkan" pada dua mata pelajaran tersebut, hingga sekarang tampaknya telah jatuh ke dalam sekedar "pengenalan nilai" atau "pengajaran nilai" yang indoktrinatif-normatif, yang hanya singgah di kepala sebentar saat pendidik menyampaikan "nasehat"nya dan sesudah itu terlupakan, tidak pernah masuk ke hati nurani peserta didik, dan tidak pemah dilaksanakan dalam kehidupan. Akibatnya, kenakalan peserta didik terjadi di mana-mana. Ini memberikan indikasi bahwa, pendidikan nilai yang dibelajarkan tidak memberikan makna signifikan bagi pembentukan kepribadian peserta didik. 


\section{B. Konsep Nilai dan Pendidikan Nilai}

Nilai (value/ qimah) merupakan hakikat sesuatu yang menyebabkan hal itu pantas dikerjakan oleh manu sia ${ }^{6}$. Selanjutnya Driyarkara menjelaskan bahwa nilai, erat kaitannya dengan kebaikan, kendati keduanya memang tidak sama, mengingat bahwa sesuatu yang baik tidak selalu bernilai tinggi bagi seseorang atau sebaliknya ?

Nilai dalam pandangan Brubacher, sebagaimana dikutip Noorsyam ${ }^{8}$, tidak terbatas ruang lingkupnya. Nilai tersebut sangat erat dengan pengertian-pengertian dan aktivitas manusia yang kompleks, sehingga sulit ditentukan batasannya. Namun demikian, nilai dapat dirumuskan sebagai sesuatu penetapan atau suatu kualitas obyek yang menyangkut suatu jenis apresiasi atau minat.

Menurut Gagne, nilai adalah nama yang diberikan kepada sikap sosial yang diterima secara luas oleh masyarakat ". Contoh sikap semacam itu adalah menghormati hukum, toleransi, demokratis, pemujaan terhadap Tuhan, dsb.

Nilai itu praktis dan efektif dalam jiwa dan tindakan manusia serta melembaga secara obyektif di dalam masyarakat. Nilai ini merupakan suatu realita yang sah sebagai suatu cita-cita yang benar dan belawanan dengan cita-cita palsu atau bersifat khayali ${ }^{10}$.

Nilai merupakan realitas abstrak. Nilai itu kita rasakan dalam diri kita masing-masing sebagai daya pendorong atau prinsip-prinsip yang menjadi pedoman dalam hidup. Sebab itu nilai menduduki tempat penting dalam kehidupan seseorang, sampai pada suatu tingkat, di mana sementara orang lebih siap untuk mengorbankan hidup mereka daripada mengorbankan nilai. Nilai yang menjadi sesuatu yang abstrak dapat dilacak dari tiga realitas sebagai berikut:

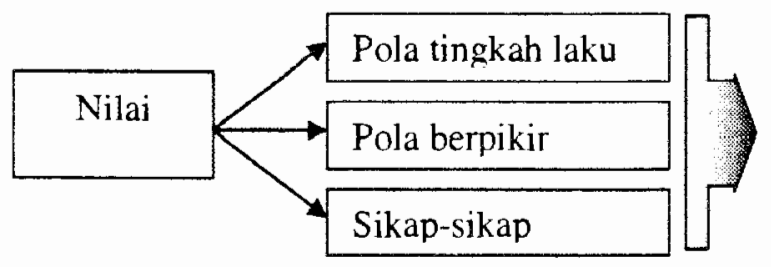

Seorang pribadi atau suatu kelompok beragama

Gambar 1: Tiga Realitas dari Nilai, Adaptasi dari Ambroise". 
Untuk mengetahui nilai, kita tidak dapat memisahkan satu-satu dari ketiga realitas tersebut. Apabila ada kecenderungan untuk melacak hanya dari polapola tingkah laku, maka hal ini akan menimbulkan pandangan yang salah atas suatu nilai tertentu, karena nilai yang sama dapat menimbulkan dua pola tingkah laku yang berbeda dalam satu, dua atau lebih kelompok masyarakat.

Sedang pendidikan adalah usaha untuk mendewasakan manusia. Terbentuknya kedewasaan ditunjukkan dengan terbentuknya pribadi yang bermoral atau moral character ${ }^{i 2}$.Pribadi yang bermoral adalah memiliki kemampuan untuk mengelola hidupnya sesuai dengan nilai-nilai luhur kemanusiaan dan ketuhanan 13 .

Berangkat dari konsepsi nilai dan pendidikan tersebut, maka dapat dirumuskan bahwa, pendidikan nilai adalah upaya untuk membentuk pribadi yang bermoral yang memiliki kemampuan untuk mengelola hidupnya sesuai dengan nilai-nilai luhur kemanusiaan dan ketuhanan. Keberhasilan pendidikan nilai ini ditunjukkan oleh terbentuknya individu yang tidak hanya mampu mengamalkan nilai-nilai tersebut, tetapi juga mampu mensosialisasikan kepada semua orang. Maka dari itu, jika dilaksanakan secara konsekuen, setiap pendidikan di sekolah harus diarahkan pada tujuan untuk merubah perilaku dari kurang baik menjadi baik yang selanjutnya nilai-nilai itu mempribadi pada diri peserta didik, sehingga mereka memiliki kemampuan untuk mengeloa hidupnya sesuai dengan nilai-nilai kemanusiaan dan ketuhanan. Kemampuan seperti itu ada pada hati nurani yang telah mencapai kedewasaan. Untuk itu, segala usaha bertujuan untuk membina hati nurani mesti diarahkan agar peserta didik mempunyai kepekaan dan penghayatan atas seperangkat nilai.

Menurut Winecoff, pendidikan nilai berbeda dengan pendidikan moral ${ }^{14}$. Pendidikan nilai berkaitan dengan keputusan moral dan non-moral pada suatu obyek, meliputi estetis (gambaran nilai suatu obyek dari kebaikan dan kepribadian) dan etik (gambaran nilai dari baik dan buruk pada kehidupan antar pribadi). Tujuan pendidikan nilai adalah proses membantu peserta didik untuk mendalami keberadaan nilai-nilai melalui ujian kritik dengan meningkatkan atau memperbaiki kualitas pemikiran dan perasaan mereka. Pendidikan nilai meliputi sedikiitnya empat dimensi pokok, yaitu: (1) mengidentifikasi suatu inti dari nilai personal dan sosial, (2) menemukan șecara filosofis dan rasional menuju suatu inti, (3) respon afektif dan emosi menuju suatu ini, dan (4) membuat keputusan hubungannya dengan basis inti pada penemuan dan respon. 
Sedang pendidikan moral adalah berkaitan dengan pertanyaan baik dan buruk pada kehidupan antar pribadi mencakup konsep, seperti HAM, martabat kemanusiaan, nilai kemanusiaan, keadilan, pertimbangan, persamaan hak, dan hubungan timbal balik. Tujuan pendidikan moral adalah membantu peserta didik untuk lebih bertanggungjawab, adil, dan pertimbangan matang tentang dirinya dan orang lain.

Antara pendidikan nilai dan pendidikan moral, keduanya membantu peserta didik untuk berubah, sehingga mereka lebih dapat dipercaya dan produktif secara personal dan sosial. Perubahan pada tingkah laku yang terjadi pada individu, biasanya didahului oleh informasi baru yang menyebabkan perubahan pada kepercayaan dasar, tingkah laku, dan nilai.

Kepercayaan adalah kumpulan dari fakta dan pendapat tentang kebenaran, keindahan, dan kebajikan. Tingkah laku adalah kerangka kepercayaan yang menentukan kecenderungan kepada obyek atau situasi yang spesifik. Nilai adalah seperangkat tingkah laku yang umum atau menyebabkan keputusan yang dibuat berhasil sesuai dengan patokan atau prinsip-prinsip di mana tindakan itu dapat diukur. Moral adalah seperangkat nilai (standar atau prinsip) yang perlu dipertimbangkan supaya dapat diterima pada konteks cultural . Sikap sungguhsungguh mengindikasikan tingkat komitmen seseorang pada tindakan atau tingkah laku pada suatu cara yang pasti. Tingkatan komitmen ini didasarkan pada nilai individu dan standar moral ${ }^{15}$.

Ilustrasi yang sangat sederhana dari "nilai" hubungannya dengan elemenelemen yang tercakup di dalam perubahan tingkah laku individu dapat digambarkan sebagai berikut:

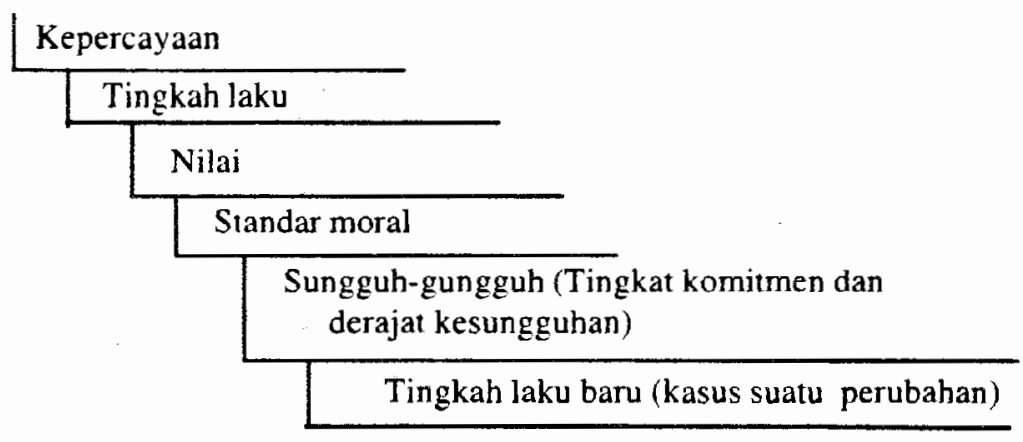

Gambar 2: Adaptasi dari Winecoff ${ }^{16}$. 


\section{Tujuan Pendidikan Nilai}

Menurut Djiwandono ${ }^{17}$, pendidikan nilai bertujuan untuk, pertama, menanamkan nilai-nilai untuk menangkis pengaruh nilai-nilai negatif atau yang cenderung mendorong nilai-nilai negatif dalam artian moral yang merupakan akibat arus globalisasi. Kedua, memerangi kecenderungan materialisme, konsumerisme, dan hedonisme, misalnya yang dapat dibawa atau sekurang-kurangnya didorong oleh arus globalisasi, ditanamkan nilai kesederhanaan dan cinta kepada sesama. Ketiga, Menanamkan pemahaman dan penghayatan nilai keadilan, karena kecenderungan-kecenderungan materialisme, konsumerisme, dan hedonisme sebenarnya dapat dianggap sebagai cermin egosime, kurang cinta kasih, dan kurang peduli terhadap orang lain.

Pendidikan nilai dikatakan berhasil jika peserta didik ada disposisi batin yang benar untuk menghayati sekaligus melaksanakan akan makna kehidupan yang disinari nilai-nilai ilahiah. Dalam penghayan dan pelaksanannya, nilai-nilai tersebut tidak dapat dipaksa dari luar, melainkan masuk ke dalam hati peserta didik secara lembut ketika hatinya secara bebas membuka diri. Dengan demikian, pendidikan nilai akan bermakna kalau dapat menginternalisasi atau mempribadi pada diri peserta didik.

Menurut Adisusilo ${ }^{18}$, beberapa tahun lalu ketika globalisasi materialisme dan konsumerisme mulai melanda tanah air, Notonagoro (1984) telah mengajukan usul bagaimana nilai-nilai universal yang bersumber dari agama, seharusnya diajarkan kepada peserta didik, agar nilai-nilai tersebut tidak hanya menjadi sloganslogan, melainkan sungguh-sungguh diamalkan dan dihayati. Notonagoro mengajukan empat langkah yang harus ditempuh agar pendidikan nilai berdaya guna, yaitu:

1. Para pendidik terlebih dahulu harus tahu dan jelas dengan akal budinya, memahami dengan hatinya nilai-nilai apa saja y ang akan diajarkan.

2. Para pendidik mentransformasikan nilai-nilai tersebut kepada peserta didik dengan sentuhan hati dan perasaan, melalui contoh-contoh konkrit dan sedapat mungkin teladan si pendidik, sehingga peserta didik dapat melihat dengan mata kepala sendiri alangkah baiknya nilai itu.

3. Langkah selanjutnya adalah membantu peserta didik untuk menginternalisasikan nilai-nilai tersebut tidak hanya dalam akal budinya, tetapi 
terutama dalam hati sanubari si peserta didik, sehingga nilai-nilai yang dipahaminya menjadi bagian dari seluruh hidupnya.

4. Peserta didik yang telah merasa memiliki sifat-sifat dan sikap hidup sesuai dengan nilai-nilai tersebut didorong dan dibantu untuk mewujudkan atau mengungkapkannya dalam tingkah laku hidup sehari-hari.

Dengan langkah-langkah tersebut diharapkan pendidikan nilai mempunyai makna strategis dalam upaya menciptakan peserta didik menjadi manusia yang ber-al-akhlaq al-karimah. Lebih dari pada itu, sesuatu yang terpenting adalah membentuk peserta didik agar tumbuh sikap keterbukaan dan kejujuran hati secara mendalam dalam menghayati akan makna nilai.-nilai kemanusiaan dan ketuhanan.

\section{Macam-macam Nilai yang perlu diajarkan di Sekolah}

Institusi sekolah selalu dipandang sebagai salah satu tempat yang sesuai untuk membentuk nilai di samping keluarga. Nilai yang penting untuk diajarkan di sekolah antara lain dikemukakan oleh Al-Maududi yang diambil dari sumber ajaran agama (Islam) sebagai berikut: (1) penghayatan akan makna iman dan taqwa. (2) sikap tolong-menolong dalam berbuat kebajikan, (3) sikap khusnudhon (baik sangka), (4) menghargai diri dan orang lain, (5) menerima tanggungjawab bagi perbuatan yang dilakukan sendiri, (6) sikap positif terhadap pendidik dan teman sekelas, (7) menjaga milik sendiri dan menjaga milik teman lain, (8) ketepatan waktu mengerjakan tugas pelajaran, dan (9) bersikap jujur, adil, dan bijaksana kepada-diri sendiri dan orang lain ${ }^{19}$.

Relevan dengan pernyataan Al-Maududi tersebut, Linda dan Eyre, menyatakan bahwa, nilai-nilai yang perlu diberikan kepada anak di sekolah dan keluarga adalah kejujuran, keberanian, cinta damai, keandalan diri dan potensi, disiplin diri dan tahu batas, serta kemurnian dan kesucian. Nilai-nilai tersebut oleh Linda dan Eyre disebut dengan nilai-nilai nurani (values of being) ${ }^{20}$. Disamping itu, juga nilai-nilai lain seperti setia dan dapat dipercaya, hormat, cinta kasih sayang, peka dan tidak egois, baik hati dan ramah, serta adil dan murah hati. Nilaj-nilai ini disebut oleh Linda dan Eyre dengan nilai-nilai memberi (values of giving) ${ }^{21}$. 
Untuk menunjukkan titik-titik awal dan arah aliran masing-masing nilai tersebut, dapat dibuat sebuah gambar sebagai berikut:

\begin{tabular}{|l|l|}
\hline Nilai-nilai Nurani (siapa kita) & Nilai-nilai Memberi (yang kita berikan) \\
\hline Kejujuran & \\
\hline Keberanian & \\
\hline Cinta Damai & \\
\hline Keandalan Diri, Potensi & \\
\hline Disiplin Diri, Tahu Batas & \\
\hline Kemurnian, Kesucian & Setia, Dapat Dipercaya \\
\hline & Hormat \\
\hline$\leftarrow$ & Cinta, Kasih Sayang \\
\hline$\leftarrow$ & Peka. Tidak Egois \\
\hline$\leftarrow$ & Baik Hati, Ramah \\
\hline$\leftarrow$ & Adil, Murah hati \\
\hline & \\
\hline &
\end{tabular}

Gambar 3: Adaptasi dari Linda \& Eyre22.

Satu pemikiran yang tersirat dalam diaram ini adalah dua metode paling penting untuk mengajarkan ke dua belas metode adalah menunjukkan siapa kita dan tindak memberi. Menunjukkan siapa kita dan tindak memberi bukan hanya menguji nilai-nilai kita, tetapi juga suatu cara untuk mengajarkan dan menularkan semua itu kepada orang lain, khususnya peserta didik.

Disamping nilai-nilai tersebut, ada beberapa nilai ilahiyah dan nilai insaniyah yang perlu juga diajarkan kepada peserta didik. Nilai-nilai ilahiyah dimaksud, antara lain: ikhlas (melakukan sesuatu hanya semata-mata karena Allah), tawadhu' (hormat dan rendah diri secara proporsional), khaya'/malu (perasaan undur seseorang seseorang sewaktu lahir atau tampak dari dirinya sesuatu yang membawa ia tercela), qanaah (menerima dengan rela apa yang ada atau merasa cukupdengan apa yang dimiliki), zuhud (tidak terpedaya oleh kehidupan duniawi atau hal-hal yang bersifat kebendaan), iffah (dapat menjaga diri dari hal-hal yang 
dapat menurunkan martabatnya), syajaah (berani karena benar), jujur (menyatakan apa adanya, tidak menambah dan tidak mengurangi), dll. Sedang nilai-nilai insaniyah, berdasarkan identifikasi penulis, paling tidak ada 16 nilai yang perlu dibelajarkan kepada peserta didik, yaitu: Kepedulian \& Empati (Menanggapi perasaan, pikiran, dan pengalaman orang lain, karena merasasakan kepedulian terhadap sesama), kerjasama (menggabungkan tenaga diri pribadi dengan orang lain untuk bekerja demi mencapai suatu tujuan), berani (kemampuan menghadapi kesulitan, bahaya, atau sakit dengan cara yang dapat mengendalikan situasi), keteguhan hati \& komitmen (bertahan dalam mencapai cita-cita, pekerjaan, dan segala urusan), adil (memperlakukan orang lain dengan sikap tidak memihak dan memperlakukan orang lain secara wajar), suka menolong (selalu siap mengulurkan tangan dan dengan secara aktif mencari kesempatan untuk menyumbang), humor (menciptakan kecerahan dalam kehidupan sehari-hari dengan tersenyum pada situasi senang dan tertawa pada situasi yang menggelikan), mandiri dan percaya diri (mempertimbangkan pilihan dan membuat keputusan sendiri), disiplin diri (membiasakan diri untuk mematuhi peraturan atau kesepakatan yang telah dibuat), loyalitas (tetap setia terhadap komitmen dengan orang lain (keluarga atau teman) atau dengan kelompok tertentu), sabar (mampu menangani kelambatan mencapai cita-cita atau kesempatan khusus dan menunggu dengan tenang), rasa bangga (perasaan senang yang dirasakan ketika menyelesaian suatu tugas yang menantang mencapai tujuan yang sulit, atau bahkan saat mendapatkan sesuatu yang diinginkan), banyak akal (kemampuan untuk berfikir secara kreatif tentang metode dan bahan yang berbeda dalam upaya menanggulangi situasi yang baru dan sukar), sikap respek (menghormati orang lain ketika mengagumi, menghargai, dan mempunyai penghargaan khusus), tanggungjawab (dapat dipercaya dan dapat diandalkan atas suatu perbuatan atau tindakan), dan toleransi (saling hormat-menghormati antar sesama tanpa memandang suku, agama, ras, dan aliran)

Nilai-nilai tersebut merupakan kaidah hidup seseorang yang akan tercermin dalam pikiran, ucapan, dan tindakan, atau lebih khusus lagi tercermin pada pakaian, teman-teman yang diplihnya, tempat kediaman, waktu rekreasi, bacaan, karya, memilih jodoh dan bagaimana orang mengadakan hubungan keluarga dengan saudara-saudaranya ${ }^{23}$. Nilai itu juga akan dengan sendirinya membantu perkembangan pribadinya, merupakan pengikat kepribadian. Persyaratan tersebut 
hanyalah merupakan komponen-komponen nilai, tiap nilai sebenamya membantu perkembangan keseluruhan pribadi peserta didik. Kalau nilai-nilai tersebut sudah menginternalisasi atau mempribadi pada diri peserta didik, maka secara reflek anak akan melakukan tindakan-tindakan yang positif, tanpa harus disuruh atau ditakut-takuti. Untuk mencapai ini, maka diperlukan strategi pendidikan nilai yang tepat, agar tujuan pendidikan nilai dapat berhasil secara optimal.

\section{Pendekatan Pendidikan Nilai di Sekolah}

Pendidikan nilai di sekolah selama ini hanya "dititipkan" pada mata pelajaran Pendidikan Agama dan Pendidikan Pancasila dan Kewarganegaraan (PPKn). Seharusnya, tidak hanya pada dua mata pelajaran tersebut, tetapi bisa kepada semua mata pelajaran. Karena pada dasarnya setiap mata pelajaran itu selalu memiliki tujuan yang ingin mengubah tingkah laku peserta didik, baik dalam hal kognitif, afektif, dan psikomotoriknya ${ }^{24}$. Khususnya mata pelajaran yang sangat erat dengan pendidikan nilai, misalnya mata pelajaran bahasa dan Ilmu Pengetahuan Sosial (IPS).

Menurut Sukron, pendidikan budi pekerti atau pendidikan nilai sangat mungkin diintegrasikan dalam pengajaran Bahasa dan Sastra Indonesia, dengan cara pendidik memilih bahan pengajaran yang mampu mempengaruhi, membentuk, mengembangkan peserta didiknya agar memiliki budi pekerti luhur (al-akhlaq al-karimah $)^{25}$. Terampil berbahasa berarti terampil dalam mengungkapkan ide, gagasan, informasi, atau perasaan. Dengan demikian, pembinaan ketrampilan berbahasa dapat dibarengi dengan pembinaan budi pekerti melalui penghayatan dan pemaknaan terhadap bahan pelajaran yang mengandung nilai-nilai ketuhanan dan kemanusiaan.

Demikian juga mata pelajaran IPS yang pokok bahasannya sarat dengan nilai-nilai kemanusiaan. Dengan penyajian bahan ini dapat menyisipkan pesanpesan nilai moral yang di arahkan pada upaya untuk membentuk pribadi peserta didik. Dengan ini diharapkan, tanggungjawab pembentukan pribadi anak tidak hanya bertumpu pada pendidik agama dan PPKn tetapi juga pendidik bahasa dan IPS serta semua pendidik yang terlibat dalam kegiatan proses belajar-mengajar di sekolah. 
Dalam pendidikan nilai sejumlah strategi pembelajaran perlu dibina dan dilatihkan serta dibakukan pada peserta didik. Yang paling utama adalah kemampuan atau ketrampilan mengidentifikasikan nilai, mengklarifikasi diri dan menilai (valueing), serta mengambil kesimpulan atau keputusan.

Menurut Martorella ${ }^{26}$, ada sejumlah pendekatan pendidikan nilai yang dapat dipilih oleh pendidik sesuai dengan tujuan dan materinya. Pendekatan ini sering disebut dengan Value Clarification Technique (CDT). Pendekatan dimaksud meliputi:

a. Evocation Approach (Pendekatan Evokasi/Ekspresi Spontan)

Pendekatan ini dilakukan dengan cara para peserta didik diberi kebebasan dan kesempatan penuh untuk mengemukakan (mengekspresikan) tanggapan perasaan, penilaian dan pandangannya terhadap suatu hal yang dijelaskan pendidik, khususnya nilai-nilai tertentu. Pandangan tersebut bahkan boleh bersifat emosional, negatif, maupun positif.

b. Enculcation Approach (Pendekatan Enkulkasi/Sugestif Terarah)

Peran pendidik dalam pendekatan ini sangat menentukan, sebab melalui stimulus yang direncanakan, peserta didik "dibawa" secara halus menuju suatu kesimpulan atau pendapat yang sudah ditentukan.

c. Awareness Approach (Pendekatan Kesadaran).

Pendidik menciptakan suatu kegiatan tertentu, seperti menyuruh peserta didik untuk membaca, mengamati, meneliti, melakukan aktifitas tertentu. Dari sini kemudian pendidik menuntun peserta didik untuk mengklarifikasi dirinya atau orang lain.

d. Moral Reasoning (Mencarai/Menentukan Kejelasan Moral)

Dalam hal ini, pendidik mendeskripsikan beberapa kasus yang bersifat dilematis kepada peserta didik. Kemudian peserta didik diajak terlibat dalam dilemma tersebut dan diminta mengklarifikasi dirinya serta meningkatkan nilai tersebut melalui dialog antar potensi dirinya atau dengan teman atau pendidik.

e. Values Analysis Approach (Pendekatan Analisis Nilai)

Dalam pendekatan ini peserta didik diajak mengadakan analisis nilai yang ada dalam suatu media atau stimulus mulai dari analisis seadanya berupa reportase sampai pengkajian secara akurat atau teliti atau tepat. 
f. Value Clarification (Pengungkapan Nilai)

Pendekatan ini yang biasa digunakan sebagai label pengajaran aféktif (nilai) dengan singkatan VCT. Dalam pendekatan ini peserta didik dibina kesadaran emosional nilainya melalui cara yang kritis rasional melalui klarifikai dan menguji kebenaran, kebaikan, keadilan, kelayakan, atau ketepatannya.

g. Commitment Approach (Pendekatan Kesepakatan)

Pendekatan ini biasanya digunakan dalam pendidikan dan pelatihan atau penataran, dimana setiap peserta sejak awal masuk sudah diminta menyepakati sikap dan pola berfikir berdasarkan acuan nilai-nilai tertentu.

h. Union Approach (Pendekatan Menintegrasikan Diri)

Dalam pendekatan ini, peserta didik diintegrasikan dalam kehidupan riil atau stimulasi yang dirancang pendidik. Dari sini kemudian peserta didik disuruh mengalami atau merasakan sesuatu yang diharapkan.

\section{Problema Pendidikan Nilai di Sekolah}

Menurut Adimassana ${ }^{27}$, pendidikan nilai yang dilakukan secara formal hampir pasti tidak akan mencapai tujuan. Karena tidak adanya disposisi peserta didik untuk membuka batinnya dan siap menerima nilai-nilai yang ditawarkan. Untuk itu, keahlian pendidik dalam menciptakan kondisi pembelajaran yang menyenangkan sangat diperlukan, agar peserta didik merasa nyaman dalam menyerap nilai-nilai yang ditawarkan oleh pendidik. Disamping itu, kesiapan pendidik dalam mengajar sangat mendukung penanaman nilai kepada peserta didik. Pendidik yang menunjukkan performansi menyenangkan di hadapan peserta didik, akan lebih berhasil dalam menanamkan nilai kepada peserta didik, apabila dibanding dengan pendidik yang "tidak berkenan" di hati peserta didik. Menurut hemat penulis, faktor pendukung dan penghambat ini secara internal terjadi pada diri peserta didik. Kalau peserta didik tidak mempunyai motivasi, kurang konsentrasi, salah memilih teman, dsb., maka pendidikan nilai tidak berhasil. Tetapi sebaliknya, kalau peserta didik mempunyai kesiapan untuk menerima pendidikan nilai, maka akan mudah berhasil. Untuk itu, suatu hal yang harus dilakukan oleh pendidik (juga orang tua) adalah memotivasi peserta didik agar membangun dalam dirinya: (a) niat untuk mengikuti acara-acara yang diselenggarakan oleh sekolah 
dalam kaitannya dengan penanaman nilai, (b) arah-perhatian yang terpusat, (c) minat yang muncul secara bebas dari dalam (merasa butuh), dan (d) keterbukaan untuk berkembang dan menerima kekurangan yang dimilikinya ${ }^{28}$.

\section{Penutup}

Berbagai nilai sebagaimana dalam kajian terdahulu tersebut, sebenarnya dapat kita temukan dalam praktek kehidupan berbangsa dan bernegara Indonesia. Misalnya, dengan melihat penyerahan diri orang-orang Indonesia saat ini kepada Tuhan, menurut gaya agama mereka masing-masing, dsb. Bahkan kalau dilihat dari sekedar segi peribadatan, nilai ketuhanan itu belumlah jelas. Sebab, bertuhan tidak hanya berarti beribadat, melainkan juga hidup sesuai dengan kehendakNya dan mempercayakan diri seluruhnya ke tanganNya. Dalam perspektif Islam, bahwa beribadah tidak sekedar menjalankan rukun Islam yang lima (ibadah mahdhoh), tetapi juga ibadah yang lain (ghoiru mahdhoh), misalnya bertanggungjawab terhadap keluarga secara moral, material, dan spiritual, menghormati orang lain, jujur, bijaksana, adil, dan lain-lain. Semua yang terakhir ini juga termasuk tindakan atau perbuatan yang bernilai ibadah (penghambaan diri kepada Allah).

Begitu pula dengan nilai kemanusiaan. Nilai ini tidak dapat ditemukan dalam bentuknya sendiri, melainkan sesuatu yang ada di balik tindakan-tindakan orangorang, sejauh mereka bertindak rasional dan manusiawi. Tindakan dimaksud misalnya, cinta dan kasih sayang terhadap sesama, adil dan bijaksana tanpa membedakan agama, ras, dan suku.

Dengan demikian, pendidikan yang bertumpu pada 2 nilai dasar (nilai ketuhanan dan kemanusiaan) tersebut berperan sangat penting dalam mewujudkan makna dan hakekat pembangunan nasional yang pada dasarnya terkait dengan nilai-nilai ini. Untuk mewujudkan cita-cita tersebut, maka diperlukan pendidikan nilai yang integratif antara keluarga, sekolah, dan masyarakat termasuk media massa. 


\section{Endnotes}

1 Hadiwardoyo, A.P. Nilai Kemanusiaan Hikmat bagi Pendidikan Dalam Kaswardi, K. (Penyunting). Pendidikan Nilai Memasuki Tahun 2000. (Jakarta: Pendidikan KWI/ MNPK \& Gramedia Widiasarana, 1993), p. 31.

2 Djiwandono, J.S. Globalisasi dan Pendidikan Nilai. Dalam Sindhunata (Ed.). Menggagas Paradigma Baru Pendidikan, Demokratisasi, Otonomi, Civil Society, Globalisasi. (Yogyakarta: Kanisius \& Universitas Sanata Dharma, 2000), p. 110.

3 Adimassana, Y.B. Revitalisasi Pendidikan Nilai di dalam Sektor Pendidikan Formal, Dalam Atmaji, A. \& Setiyaningsih, Y. (Ed.). Transformasi Pendidikan Memasuki Milenium Ketiga. (Yogyakarta: Kanisius \& Universitas Sanata Dharma, 2000), p. 30.

$4 \quad$ Muhaimin, dkk., Strategi Belajar Mengajar : Penerapannya Dalam Pembelajaran Pendidikan Agama, (Surabaya : Citra Media, 1996), p. 34.

5 Sukron, M. Pendidikan Budi Pekerti dalam Pengajaran Bahasa. Dalam Mimbar Pembangunan Agama. No. 181/Rajab-Sya' ban 1422 H/Oktober 2001/Th. XVI, P. 38.

* Driyarkara, N. Percikan Filsafat. (Djakarta: Djambatan, 1966), p. 38.

7 Ibid.

* Noorsyam, M. Filsafat Pendidikan dan Dasar Filsafat Pendidikan Pancasila. (Surabaya: Usaha nasional, 1986), p. 133.

9 Gagne, R.M. The Conditions of Learning and Theory of Instruction. (Japan: Holt, Rinehart and Winston Holt-Saunders, 1985), p. 236.

10 Tbid.

11 Ambroise, Y. Pendidikan Nilai. Dalam Kaswardi, K. (Penyunting). Pendidikan Nilai Memasuki Tahun 2000. (Jakarta: Pendidikan KWI/MNPK \& Gramedia Widiasarana. I993), p. 20.

12 Montemayor, F.M. Ethics: The Philosophy of Life (Manila: National Book Store, Inc, 1994), P. 11.

13 Adimassana, Y.B. Op. cit., p. 35.

i4 Winecoff, H.L. Values Education: Concepts and Models (Bandung: FPS IKIP, 1987/ 1988), p. 3.

is Ibid., p. 4.

i6 Ibid., p. 4.

17 Djiwandono, J.S., Op.cit., p. 110.

Ix Adisusilo, J.R.S. Pendidikan Nilai dalm Ilmu-Ilmu Sosial-Humaniora. Dalam A tmaji, A. \& Setiyaningsih, Y. (Ed.). Transformasi Pendidikan Memasuki Milenium Ketiga. (Yogyakarta: Kanisius \& Universitas Sanata Dharma, 2000), p. 74-75. 
19 Al-Maududi, A.A. Islam sebagai Pandangan Hidup. Terj. Iqbal, M.S. (Bandung: Sinar Baru, 1983), p. 70-71.

20 Linda \& Eyre, R. Mengajarkan Nilai-Nilai Kepada Anak. Alih Bahasa Widodo, A.T.K. (Jakarta: SUN, 1999), p. xxvi.

21 Ibid.

$22 \quad$ Ibid., p. xxvii.

23. Sastrapratedja, M. Pendidikan Nilai. Dalam Kaswardi, EM.K. (Penyunting). Pendidikan Nilai Memasuki Tahun 2000. (Jakarta: Pendidikan KWI/MNPK \& Gramedia Widiasarana, 1993), p. 8.

24 Sukron, M. Op. cit., p.38.

25 Ibid.

26 Mortorella, P.P. Social Study Strategies Theon into Practise. (London:Haper and Row Publishing Company, 1976), p. 40-46.

27 Op. cit., p. 39-40.

2k. Zuraiq, M. Pedoman Mendidik Anak Menjadi Shaleh dan Shaliha. (Yogyakarta: Bintang Cemerlang. 2001)

\section{BIBLIOGRAFI}

Adimassana.Y.B., Revitalisasi Pendidikan Nilai di Dalam Sekior Pendidikan Formal, dalam A. Atmadi dan Y. Setiyaningsih (Ed) Transformasi Pendidikan Memasuki Milinium Ketiga, (Yogyakarta : Kanisius,2000)

Adisusilo,S.J.R., Pendidikan Nilai Dalam Ilmu-ilmu Sosial-Humaniora, dalam A. Atmadi dan Y. Setiyaningsih (Ed) Transformasi Pendidikan Memasuki Milinium Ketiga, (Yogyakarta : Kanisius,2000)

AI-Maududi, A.A. Islam sebagai Pandangan Hidup. Terj. Iqbal, M.S. (Bandung: Sinar baru, 1983),

Ambroise, Yyon S.J, Pendidikan Nilai, dalam Kaswardi, EM.K.. Pendidikan Nilai Memasuki Tahun 2000, (Jakarta: Gramedia, 2000).

Brand, D.L. Educating for Character in The Unitet States Army: A Study to Determine The Components for An Effective Curriculum for Values Education in Basic Training (Ann Arbor: UMI Company, 1999). 
Djiwandono, J.S. Globalisasi dan Pendidikan Nilai. Dalam Sndhunata (Ed.). Menggagas Paradigma Baru Pendidikan, Demokratisasi, Otonomi, Civil Society, Globalisasi. (Yogyakarta: Kanisius \& Universitas Sanata Dharma, 2000),

Driyarkara, N. Percikan Filsafat. (Djakarta: Djambatan, 1966).

Echols, J.M. \& Shadily, H. Kamus Inggris Indonesia. (Jakarta: Gramedia Pustaka Utama, 1984).

Gagne, R.M. The Conditions of Learning and Theory of Instruction. (Japan: Holt, Rinehart and Winston Holt-Saunders, 1985).

Hadiwardoyo, A.P. Nilai Kemanusiaan Hikmat bagi Pendidikan. Dalam Kaswardi. K. (Penyunting). Pendidikan Nilai Memasuki Tahun 2000. (Jakarta: Pendidikan KWI/MNPK \& Gramedia Widiasarana, 1993), p. 31.

H.J.Kalusmeier, Learning and Human Abilities : Educational Psychology. (New York: Harper 1975)

Kartono, ST. Menabur Benih Keteladanan, Kumpulan Esei Seorang Pendidik. (Yogyakarta: KEPEL Press, 2001).

Krathwohl, D.R., dkk., Taxonomy of Educational Objectives : The Classification of Educational Goal. Hand Book II : Affective Domain, (New York : Longman, 1964).

K. Bertens, Etika (Jakarta : Gramedia, 1999)

Linda \& Eyre, R. Mengajarkan Nilai-Nilai Kepada Anak. Alih Bahasa Widodo, A.T.K. (Jakarta: SUN, 1999),

Martin, B.L. and Briggs, L.J., The Affective and Cognitive Domains : Integration for Instruction and Research. (New Jersey : Educational Technology Publishers, 1986).

Montemayor, F.M. Ethics: The Philosophy of Life (Manila: National Book Store, Inc, 1994),

Mortorella, P.P. Social Study Strategies Theory into Practise. (London:Haper and Row Publishing Company, 1976),

Muhadjir, N. Ilmu Pendidikan dan Perubahan Sosial, Teori Pendidikan Pelaku Sosial Kreatif. (Yogyakarta: Rake Sarasin, 2000). 
Munandar, S.C.U. Mengembangkan Bakat dan Kreativitas Anak Sekolah, Petunjuk bagi Para Guru dan Orang Tua. (Jakarta: Gramedia Widiasarana Indonesia, 1995).

Murphy, J.J. A critical, Philosophical Examination of Moral Reasoning and Moral education in Current Educational Models and A Porposition for A New, Alternative, Comprehensive Moral Education Model in Elemntery Grades 4-6. ( Ann Arbor: UMI Company, 1998).

Noorsyam, M. Filsafat Pendidikan dan Dasar Filsafat Pendidikan Pancasila. (Surabaya: Usaha nasional, 1986),

R. Hogan, Moral Conduct and Moral Character, A Psychological Perspective. Psychological Bulletin, 1973

Sastrapratedja S.J, M. Pendidikan Nilai, dalam Kaswardi, EM.K., Pendidikan Nilai Memasuki Tahun 2000, (Jakarta : Gramedia, 2000).

Seels, B.B. \& Richey, R.C. Instructional Technology: The Definition and Domains of the Field. (Washington DC: AECT, 1994).

Sukron, M. Pendidikan Budi Pekerti dalam Pengajaran Bahasa. Dalam Mimbar Pembangunan Agama. No. 181/Rajab-Sya'ban 1422 H/Oktober 2001/ Th. XVI. P. 38.

Winecoff, H.L. Values Education: Conceps and Models. (Bandung: PPS IKIP, 1987/1988). 